\title{
Seasonal dynamics of Sargassum ilicifolium (Phaeophyta) on a shallow reef flat in the southern Red Sea (Eritrea)
}

\author{
M. Ateweberhan ${ }^{1,2}$, J. H. Bruggemann ${ }^{1,2,3,4}$, A. M. Breeman ${ }^{2, *}$ \\ ${ }^{1}$ Department of Marine Biology and Fisheries, University of Asmara, PO Box 1220, Asmara, Eritrea \\ ${ }^{2}$ Department of Marine Biology, University of Groningen, PO Box 14, 9750 AA Haren, The Netherlands \\ ${ }^{3}$ Department of Experimental Zoology, Wageningen University, PO Box 338, 6700 AH Wageningen, The Netherlands
}

${ }^{4}$ Present address: Laboratoire d'Ecologie marine, Université de La Réunion, BP 7151, 97715 Saint-Denis, La Réunion, France

\begin{abstract}
The seasonality of Sargassum ilicifolium was studied in the southern Red Sea by monitoring thallus density, thallus size and the initiation, growth, reproduction and survivorship of primary laterals. Thallus density showed slight but significant seasonal variation; it was highest at the end of the hot season and lowest at the end of the cold season. Mean thallus and lateral lengths peaked in the second half of the cold season. Initiation of new laterals was highest in the first half of the cold season. High lateral densities suppressed new lateral initiation. In the first month after initiation, laterals grew out to the same length as those formed earlier in the year. Thus, elongation rates of young laterals were highest during the period of maximum canopy height. In older laterals, growth rates decreased with length, due to increased tissue loss. Growth rates were independent of reproductive status. Reproduction occurred in the second half of the cold season and was independent of lateral size, but laterals had to be at least 1 to 2 mo old before reproducing. Highest loss rates of laterals occurred at the end of the growth season. Survivorship was independent of lateral size or reproductive status. Loss rates were lowest in the hot season. We conclude that there is no direct trade-off between reproduction and growth/survival of the laterals, and that the dynamics of S. ilicifolium are directly related to the seasonal extremes in environmental conditions. Morphogenetic responses at the level of individual laterals also contribute to the overall phenological pattern.
\end{abstract}

KEY WORDS: Module dynamics $\cdot$ Seasonality $\cdot$ Growth $\cdot$ Size equalisation $\cdot$ Reproduction $\cdot$ Trade-off Survivorship $\cdot$ Density $\cdot$ Phenology

- Resale or republication not permitted without written consent of the publisher

\section{INTRODUCTION}

The distribution and population structure of Sargassum species is influenced by water temperature, especially antecedent events in minimum and maximum values (Ang 1986, Glenn et al. 1990), tidal levels and water movement (Ang 1986), substrate type (McCook 1999), propagule dispersal and recruitment (Hales \& Fletcher 1990, Kendrick \& Walker 1991, 1995), and herbivory (Wanders 1976, McCook 1996, 1997). Most tropical Indo-Pacific species of Sargassum reach peak abundance and reproduce during the cooler months of the year (e.g. Tsuda 1972, De Wreede 1976, Trono \&
Tolentino 1993). In other tropical areas (e.g. Great Barrier Reef: Vuki \& Price 1994, Rogers 1997; CaribbeanAtlantic: Prince 1980, De Ruyter van Steveninck \& Breeman 1987, De Guimaraens \& Coutinho 1996), Sargassum species grow and reproduce during periods with higher temperatures. Contrasting seasonal patterns in species occurring in the same region (e.g. Prince 1980), or even at the same location (e.g. MartinSmith 1993), have also been reported.

Seasonal cycles of growth and attrition in Sargassum appear to be closely related to cycles of sexual reproduction (e.g. McCourt 1984, Glenn et al. 1990), suggesting a trade-off between reproduction and growth. 
Based on the assumption of resource trade-off, De Wreede \& Klinger (1988) predicted that (1) an organism must attain a certain size in order to begin reproduction; (2) a reduction or cessation of growth would be likely at the onset of reproduction because of partitioning of resources; and (3) an organism would be more likely to die after producing and releasing reproductive structures or propagules. Such a trade-off could be more important in determining seasonal cycles than direct environmental control. However, among the algae reproduction may be cost-free or cost-reduced because reproductive structures are photosynthetic (McLachlan \& Bidwell 1978) and may be self-supporting in terms of carbon budgets (De Wreede \& Klinger 1988).

Many species of Sargassum are 'pseudoperennials' that shed their laterals after reproduction and survive unfavourable conditions with their resilient and perennial holdfast system. Seasonal patterns in growth and reproduction, therefore, take place at the level of the primary laterals (Tsuda 1972, Fletcher \& Fletcher 1975, De Wreede 1976, Prince 1980, Ang 1985, Trono 1992, McCook 1996), rather than at the level of the whole thallus. However, data on the dynamics of primary laterals are still very scarce (e.g. De Ruyter van Steveninck \& Breeman 1987). Such data might help in interpreting the seasonal patterns found in whole thalli.

The southern Red Sea is characterised by extreme seasonality in environmental conditions and biological processes, which are driven by the Indian Ocean monsoon system. In the cold season, shallow reef flats are dominated by large standing crops of macroalgae mainly composed of Sargassum and Turbinaria that decline in biomass during the hot season (Mergner \& Svoboda 1977, Lipkin 1987, Walker 1987, Sheppard et al. 1992, Ateweberhan 2004). Although the distinctive seasonality in environmental factors and biological phenomena in the Red Sea has been well documented, qualitative and quantitative information on how individual species cope with this seasonality is lacking (Lipkin 1987, Medio et al. 2000, Sheppard 2000).

Sargassum ilicifolium (Turner) C. Agardh, the species under investigation, occupies hard substrata in the lower intertidal and upper subtidal zones. It is widely distributed in the Indian Ocean (Srinivasan 1967, Silva et al. 1996) and is probably the most abundant and widely distributed Sargassum species on the southern Red Sea coasts of Eritrea (M. Ateweberhan \& J. H. Bruggemann pers. obs.).

This study aims at understanding the seasonal dynamics of Sargassum ilicifolium. By monitoring temporal patterns in density and in thallus and primary lateral parameters, we investigate responses to the extreme seasonal environment and their demographic and life history consequences. Specific questions were the following:
(1) Is there seasonal variation in thallus density and size, and how predictable are the seasonal patterns?

(2) Does the dynamism occur at the level of whole thalli, primary laterals or both?

(3) Is there seasonality in primary lateral initiation, growth and survivorship, and do growth and survivorship depend on lateral size, age or reproductive status?

(4) Does reproduction depend on lateral size, age or season, and is there a trade-off between reproduction and the growth/survival of the laterals?

\section{MATERIALS AND METHODS}

Study site. This study was conducted at Sheikh Said Island (also called Green Island; $15^{\circ} 35^{\prime} \mathrm{N}, 39^{\circ} 29^{\prime} \mathrm{E}$; Fig. 1), near the port town of Massawa, Eritrea. On the subtidal reef flats 3 distinct zones are discerned. At 0 to $1 \mathrm{~m}$ depth, Sargassum ilicifolium forms a conspicuous belt, marking the transition between the intertidal and the subtidal parts of the reef flat. Adjacent to the coraldominated fore reef, which starts at about $1.5 \mathrm{~m}$ depth, the lowest zone of the reef flat is dominated by the canopy-forming alga Turbinaria triquetra. In the cold season, the foliose brown algae Dictyota cervicornis and Stoechospermum polypodioides dominate in the zone between $S$. ilicifolium and T. triquetra (Ateweberhan 2004). Near Massawa, the tidal amplitude is small (about $0.7 \mathrm{~m}$ ). However, mean sea levels are about 10 to $20 \mathrm{~cm}$ lower in the hot season than during the rest of the year (Morcos 1970), and the shallowest parts of the reef flat become occasionally emerged in summer.

Environmental conditions. Seawater temperature was measured daily to the nearest $0.2^{\circ} \mathrm{C}$ at $2 \mathrm{~h}$ intervals. Readings were taken at $2.5 \mathrm{~m}$ depth from September 1999 to July 2001 and in the Sargassum ilicifolium zone from March to July 2001, using underwater temperature loggers (Onset Optic Stow-Away, Onset Computer; Guillaume et al. 2000). Irradiance data were derived from Meteosatellite images (Eritrea Climate, Energy, Environment and Technology site: www. punchdown.org/rvb). Rainfall data were obtained from Fantoli (1966; for 1947 to 1961) and from the Research Unit of the Ministry of Fisheries, Eritrea (Ministry of Fisheries, Eritrea, unpubl. data; for 1996 to 2000). In the context of the Indian Ocean monsoon, the period from November to April is referred to in this study as the NE monsoon or the cold season, and the period from May to October as the SW monsoon or the hot season.

Thallus density. In an earlier study (Ateweberhan 2004), no significant temporal variation in thallus density was detected during bimonthly monitoring of randomly placed quadrats (1998 to 2000). Therefore, in the present study, thallus densities were monitored more 




Fig. 1. Map of Massawa, southern Red Sea, with location of the study site at Sheikh Said Island (arrow). Dashed lines indicate the partition between intertidal and subtidal zones of the reef flats; solid lines indicate the perimeter of the reef flats

closely by using permanent quadrats. In September 1999,10 quadrats $\left(0.5 \times 0.5 \mathrm{~m}^{2}\right)$ were randomly selected within the Sargassum ilicifolium belt and marked with stainless-steel nails at their corners. Coloured synthetic ropes were attached to the nails for easy retracing, and densities were monitored at monthly intervals from September 1999 to August 2000, December 2000 to April 2001 and in July 2001.

Seasonal dynamics of thalli and primary laterals. The dynamics of Sargassum ilicifolium thalli were studied by monitoring tagged thalli and primary laterals. Thirty thalli were randomly selected along a $50 \mathrm{~m}$ transect in September 1999 and tagged by placing numbered labels around the bases of their main axes, and by nailing numbered tags close to their holdfasts. Thalli and laterals were monitored at monthly intervals from September 1999 to August 2000, December 2000 to April 2001 and in July 2001. Lost thalli were replaced at every census. In each thallus, all primary laterals $\geq 2 \mathrm{~cm}$ in length were tagged and labelled by tying tie-wraps around their lower parts, each marked with its own serial number. Every month, the length and number of primary laterals of each thallus were determined. The length and the presence of vesicles and receptacles were recorded for each primary lateral. At every census, newly appeared primary laterals were tagged. New laterals could be distinguished from older ones because of their smooth texture. As all laterals were tagged and each lateral was identified by its own serial number, old laterals that had lost their tags could be easily identified because of the missing serial number. Lost tags were replaced immediately. In general, tag loss was low $(<5 \%)$, except in January 2000, when many laterals and tags were lost due to heavy grazing by rabbitfishes (Siganidae) (M. A. pers. obs.). Therefore data on lateral growth were omitted for the December-January interval, and lateral persistence was recorded only from January onward. During each census, thirty thalli in roughly the same size range as the tagged thalli were haphazardly selected from the population (referred to as 'selected thalli' hereafter) to check for possible adverse effects of tagging. Thallus length, the number and length of all primary laterals on a thallus, and the presence of receptacles on each primary lateral were recorded.

Data analysis. Temporal variation in thallus density was analysed with repeated-measures ANOVA, using the Greenhouse-Geisser correction to accommodate for violation of the sphericity assumption (Stevens 2002). Temporal patterns in density variation were further documented by calculating, for each quadrat, the difference between the density in each month and the mean density over all censuses.

Length-frequency distributions of primary laterals in different developmental stages were determined for each month. The following stage classes were distinguished: (1) laterals without vesicles or receptacles; (2) 'vesiculate' laterals bearing vesicles but no receptacles; (3) 'fertile' laterals bearing receptacles (which usually also bore vesicles). Length-frequency distributions for the same month of the $2 \mathrm{yr}$ of monitoring were compared with chi-square tests.

Temporal variation in thallus and primary lateral parameters of tagged thalli was analysed with repeatedmeasures ANOVA as described above. For each thallus, thallus length, the mean number (total and new) and length of primary laterals, the percentage of fertile laterals and the mean and maximum growth rate were determined. Maximum growth rates refer to the fastest-growing lateral per thallus. Growth rates of shoots of large canopy algae have been reported either as absolute growth rates (= elongation rates) (e.g. De Ruyter van Steveninck \& Breeman 1987, Viejo \& Åberg 2001) or as relative growth rates (RGR) (e.g. Schaffelke \& Klumpp 1997). Both measures are presented here for comparison with published data. Elongation rate was calculated as the difference in length between 2 con- 
secutive measurements $\left(\mathrm{cm} \mathrm{mo}^{-1}\right)$. RGR was calculated with the formula:

$$
\mathrm{RGR}=\left[\ln \left(\text { length at } t_{2}\right)-\ln \left(\text { length at } t_{1}\right)\right] /\left[t_{2}-t_{1}\right]
$$

and expressed as $\% \mathrm{~d}^{-1}$ of the initial length. As tissue loss may occur between consecutive measurements, these growth rates reflect the apparent, rather than the actual, growth of laterals.

Survivorship of laterals was analysed as percentage survival ( $\log _{10}$-transformed) of cohorts formed in different months (Begon et al. 1990); data were pooled for all thalli. Survivorship curves for September 1999 to January 2000 were not included due to the loss of tags in January 2000 (see above).

Possible relationships between various thallus and primary lateral parameters were investigated. All analyses were carried out for each month separately because relationships between parameters may change with season. Moreover, data on tagged primary laterals are not independent over time. At the level of whole thalli, the following analyses were performed. Effects of lateral density (number of laterals per thallus) on mean lateral length, maximum elongation rate and formation of new laterals were analysed with regression analysis. In the analyses of new lateral formation versus lateral density, the number of new laterals in each month was regressed against the number of laterals present both in that month and in the previous month. The same procedure was used for the analysis on maximum elongation rate versus lateral density. Possible effects of thallus and mean primary lateral length on new lateral formation were also tested with linear regression.

At the level of primary laterals, the following analyses were performed, based on pooled data for all tagged thalli. The effect of age on primary lateral length was examined with 1-way ANOVA. Differences in length related to reproductive-state transitions were also analysed with ANOVA, comparing the lengths of laterals remaining sterile, starting reproduction, continuing reproduction or losing their reproductive status. Similarly, a possible effect of lateral length on the occurrence of tissue loss was examined by comparing the lengths of laterals that showed positive and negative growth over the following month. Possible effects of reproductive status and lateral length on elongation rates were analysed with general linear model ANCOVA. In order to minimise confounding effects of tissue loss (which depended on lateral size), only laterals showing positive growth were considered. The relationships between lateral length and elongation rate were further investigated with regression analysis. A possible effect of lateral length on lateral persistence was examined by comparing the lengths of laterals that did and did not persist into the following month (1-way ANOVA). The analysis was restricted to the period March to July, when loss rates were high. A possible effect of developmental stage (presence of receptacles; presence of vesicles) on lateral persistence was analysed with chi-square tests. The analysis was restricted to the period March to July, when high loss rates coincided with reproduction.

All statistical tests and analyses were performed in accordance with Sokal \& Rohlf (1995), Underwood (1997), Zar (1996) and Stevens (2002) using SPSS version 11.

\section{RESULTS}

\section{Environmental parameters}

Mean monthly seawater temperatures on the forereef at $2.5 \mathrm{~m}$ depth ranged from $27.7^{\circ} \mathrm{C}$ in winter (January) to $33.4^{\circ} \mathrm{C}$ in summer (August) (Fig. 2A). Mean daily maxima ranged from 28.4 to $34.1^{\circ} \mathrm{C}$, mean daily minima from 26.5 to $32.6^{\circ} \mathrm{C}$. Highest temperatures of the month exceeded $34.5^{\circ} \mathrm{C}$ in summer (June to August), and lowest temperatures of the month were below $25^{\circ} \mathrm{C}$ in winter (January to March). Daily temperature maxima in the shallow Sargassum ilicifolium zone were well above those recorded on the fore reef, regularly exceeding $36^{\circ} \mathrm{C}$ in the hot season, and were characterised by high variability (Fig. 2B). Daily temperature minima in the shallow $S$. ilicifolium zone were somewhat lower or equal to those recorded on the forereef at $2.5 \mathrm{~m}$ depth, which implies that the daily temperature range on the shallow reef flat was much higher than that on the fore reef (Fig. 2B). Surface irradiance ranged from $2.8 \mathrm{kWh} \mathrm{m}^{-2}$ in January to $6.1 \mathrm{kWh} \mathrm{m}^{-2}$ in September and October (Fig. 2C). Mean rainfall was $0 \mathrm{~mm}$ in June and $35 \mathrm{~mm}$ in December (Fig. 2C). Average monthly values for the wet (November to March) and dry (May to September) seasons were 26.1 and $4.3 \mathrm{~mm}$, respectively. The monthly averages of the 3 environmental parameters were strongly correlated: $\mathrm{r}=+0.854$ for water temperatureirradiation; $\mathrm{r}=-0.870$ for water temperature-precipitation; $\mathrm{r}=-0.783$ for irradiation-precipitation (Pearson's correlation: $\mathrm{p}<0.05)$.

\section{Thallus density and size}

Thallus density showed slight but significant variation over time (repeated-measures ANOVA: $\mathrm{p}<0.0001$ ). Mean densities for the 10 quadrats ranged from 41 to 47 thalli $\left(0.25\right.$ ind. $\left.\mathrm{m}^{-2}\right)$. Values decreased gradually from the beginning of the cold season in October/ November, were lowest in April/May and increased from the beginning of the hot season (June/July; 

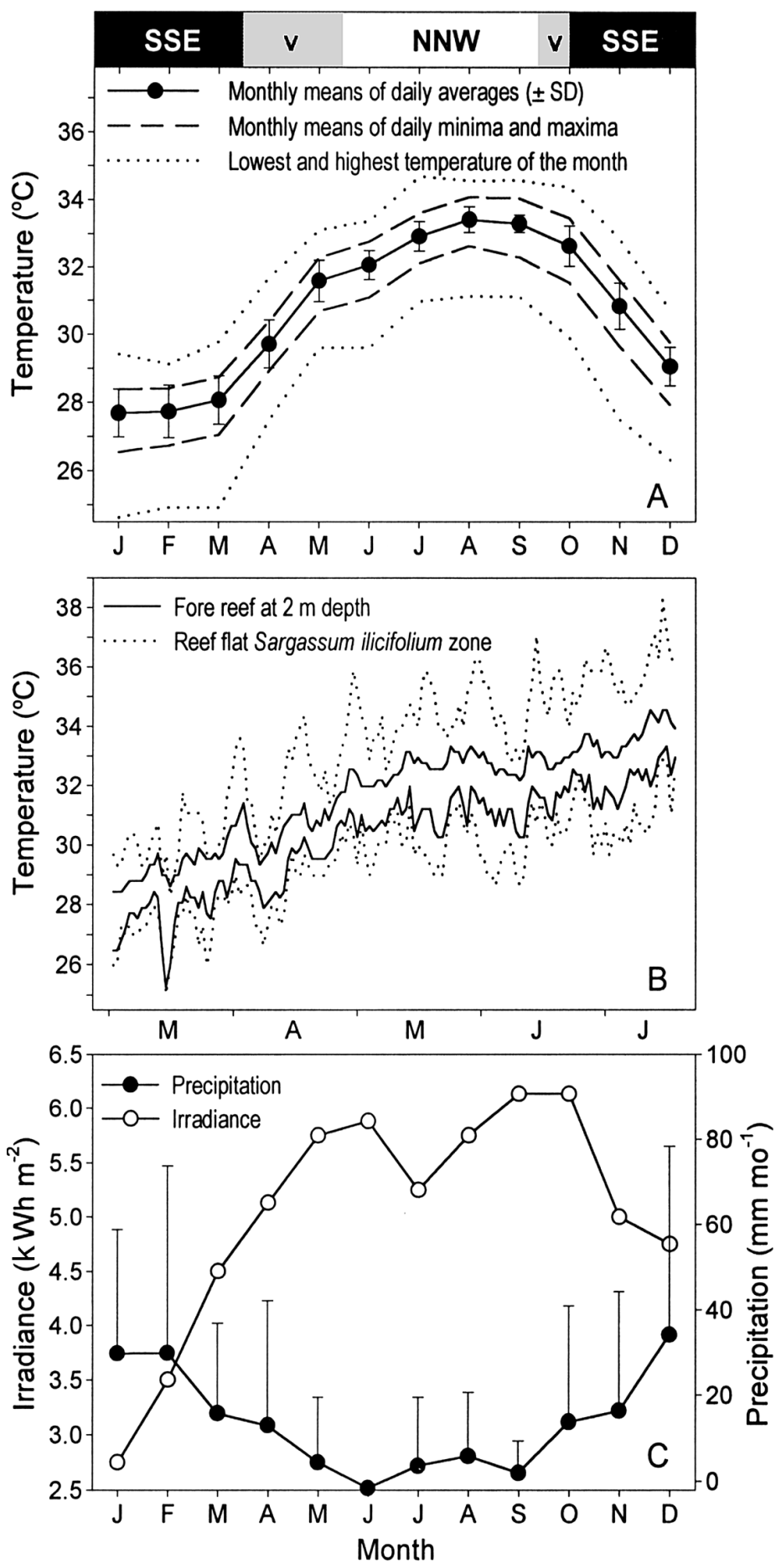

Fig. 2. Monthly variation in temperature, irradiation and precipitation. (A) Seawater temperatures recorded at $2.5 \mathrm{~m}$ depth on the fore reef, about $70 \mathrm{~m}$ seaward of the study site. Bar above indicates the general cycle of monsoon winds in the southern Red Sea: SSE during the cold season (NE monsoon); NNW during the hot season (SW monsoon); $\mathrm{v}=$ transition period with variable wind directions. (B) Comparison of maxima and minima in seawater temperature between the fore reef and the Sargassum ilicifolium zone. (C) Long-term monthly means of irradiance and precipitation

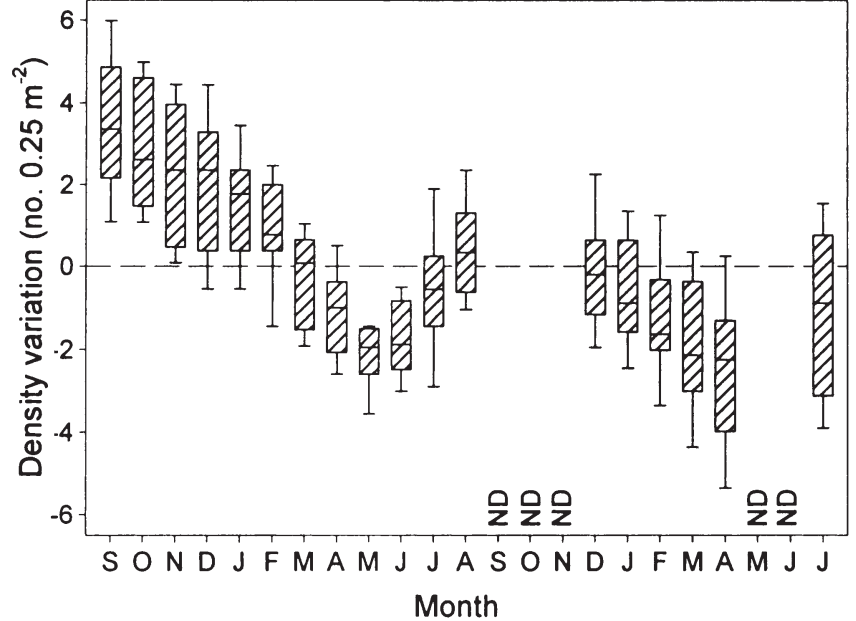

Fig. 3. Sargassum ilicifolium. Monthly variation in thallus density. For each quadrat $\left(0.25 \mathrm{~m}^{2} ; \mathrm{n}=10\right)$, the difference between the density in each month and the mean density over all censuses was calculated. Box-whisker plots show the median (horizontal lines), 25th/75th percentiles (shaded bars) and 10th/90th percentiles (vertical lines) for the 10 quadrats; $\mathrm{ND}=$ no data. Overall mean density: 43.5 thalli $0.25 \mathrm{~m}^{-2}$

Fig. 3). Out of the thirty thalli that were tagged in September 1999, 1 was lost in March 2000, 1 in March 2001, 2 in April 2000 and 3 in May 2000.

Thallus length varied strongly with season (repeatedmeasures ANOVA: $\mathrm{p}<0.0001$; Fig. 4A). Values increased from November onwards, peaked between February and May, declined abruptly in June and were lowest from July to October. The increase in thallus length between November and February was interrupted in January in the tagged thalli, due to heavy grazing by rabbitfishes (Siganidae) (M. Ateweberhan pers. obs.).

\section{Primary lateral length, number and reproduction}

Primary lateral length, number and proportion of fertile laterals also showed strong seasonal variation (repeated-measures ANOVAs: $p<0.0001$ for all parameters; Fig. 4B-D). Primary lateral length started to increase in November, was highest from February to May, and was lowest from July to October (Fig. 4B). The increase in primary lateral number started slightly later than the increase in length (Fig. 4C). In general, lateral density (number of laterals per thallus) had no significant effect on mean lateral length (regression analyses: $p \geq 0.05$ in all months except June 2000 $\left[F_{1,29}=11.87, \mathrm{p}=0.002\right.$, negative relationship $]$ ).

The proportion of fertile laterals increased sharply between January and March, was high until May and decreased strongly in June. Virtually no fertile laterals 


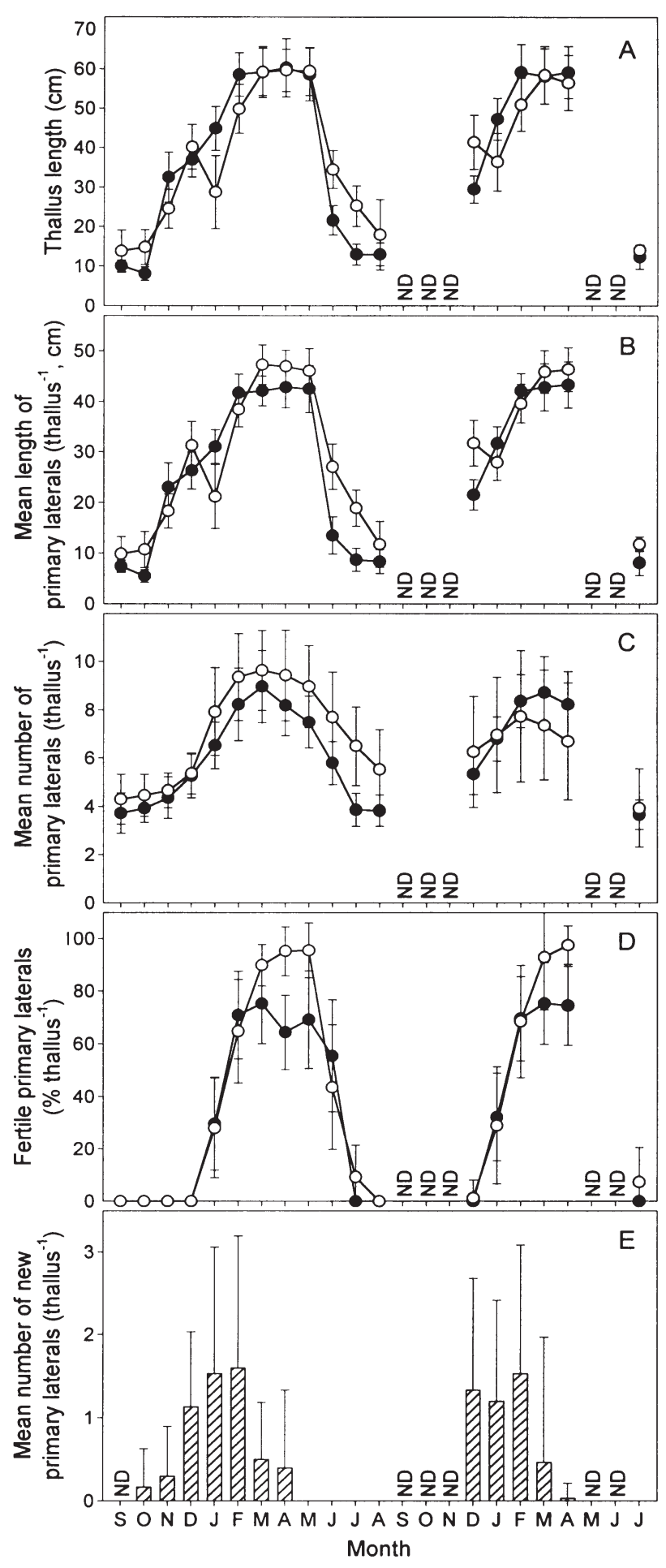

Fig. 4. Sargassum ilicifolium. Monthly variation in thallus length and primary lateral parameters. (A) Mean thallus length $( \pm \mathrm{SD})$; (B) mean length of primary laterals per thallus $( \pm \mathrm{SD}) ;(C)$ mean number of primary laterals per thallus $( \pm \mathrm{SD})$; (D) mean percentage of fertile primary laterals per thallus $( \pm \mathrm{SD})$; (E) mean number of newly formed primary laterals on tagged thalli $( \pm$ SD). Data based on tagged $(\mathrm{O})$ and selected

(๑) thalli (both $\mathrm{n}=30$ ); ND: no data occurred between July and December (Fig. 4D). Data on tagged laterals showed that nearly all laterals that persisted to the end of the reproductive season (July) had born receptacles at some stage $(94.5 \%$ in 2000 , $98.6 \%$ in 2001). Only some laterals that were formed in the last month of lateral initiation (April, see Fig. 4E) failed to reproduce in the same year. Most laterals that persisted into their second cold season reproduced again $(94 \%$ of those that survived until peak reproduction in February to April). Reproductive-stage transitions (laterals remaining sterile, becoming fertile, continuing reproduction or losing their reproductive status) were generally independent of lateral length (1-way ANOVAs: $\mathrm{p} \geq 0.05$ in SNK post-hoc tests). Only in July 2000 were laterals starting reproduction shorter than those already fertile (1-way ANOVA: $F_{3,195}=2.90$, $\mathrm{p}=0.036)$. Reproduction depended on lateral age. None of the laterals formed between January and April, when reproduction coincided with lateral initiation (see Fig. 4D,E), became fertile within the first month. Reproduction was independent of age in older laterals (1-way ANOVAs: $p \geq 0.05$ in all months).

Length class-frequency distributions of primary laterals in different developmental stages are shown in Fig. 5. Laterals without vesicles and receptacles predominated between July and November (black bars). Laterals with vesicles but no receptacles (Fig. 5, grey bars) were found mainly at the beginning (November to January) and end (June, July) of the growth season. They were represented in virtually all size classes. At the beginning of the growth season, this stage group was mainly composed of newly formed laterals and laterals that had persisted over the hot season. At the end of the growth season they consisted of laterals that had previously born receptacles. Laterals with receptacles (which usually also bore vesicles) predominated between February and May; they were also represented in most size classes (Fig. 5, white bars). Size distributions of all stage groups showed an overall shift towards larger size classes between October and March, remained stable between March and May, and shifted towards smaller size classes between May and August. Size distributions were similar in the same month of the 2 years (chi-square tests: $p \geq 0.05$ ), except in January, when grazing reduced lateral lengths in the first year (chi-square: p < 0.0001), and in July, when the decrease in size was stronger in the second than in the first year (chi-square: $p<0.0001$ ) (Fig. 5).

\section{Initiation of primary laterals}

The initiation of primary laterals also varied significantly over time (repeated-measures ANOVA: $\mathrm{p}<0.0001$; Fig. 4E). New lateral formation had started 


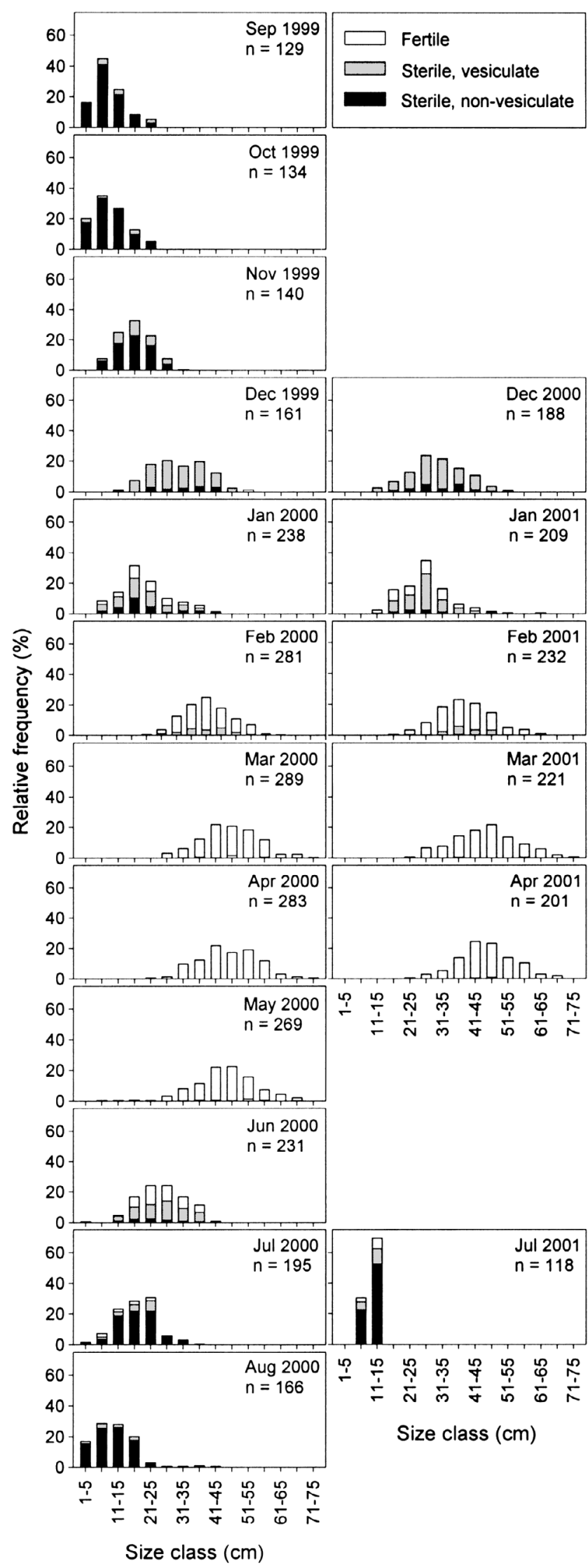

by October, reached highest values from December to February, and declined in the following months. Not a single new primary lateral appeared from May to August. Lateral initiation showed a significant negative relationship with lateral density in all months of the first year (regression analyses: October, $F_{1,29}=12.06$, $\mathrm{p}=0.002$; November, $F_{1,29}=23.83, \mathrm{p}<0.0001$; December, $F_{1,29}=8.945, \mathrm{p}=0.006$; February, $F_{1,29}=7.452$, $\mathrm{p}=0.011 ;$ March, $F_{1,28}=5.639, \mathrm{p}=0.012 ;$ April, $F_{1,27}=5.622, \mathrm{p}=0.025$ ), and regression coefficients were also negative in all months of the second year. Thallus and primary lateral length generally had no effect on primary lateral initiation (regression analyses: $\mathrm{p} \geq 0.05$ in all months except October 1999 [thallus length, $F_{1,29}=5.014, \mathrm{p}=0.033$; mean lateral length: $F_{1,29}=6.30, \mathrm{p}=0.018$; coefficients negative]).

\section{Growth rates of primary laterals}

Growth rates of primary laterals were highest during the cold season and lowest at the beginning of the hot season (Fig. 6A,B; repeated-measures ANOVAs, $\mathrm{p}<0.0001$ for both RGR and elongation rate). Mean as well as maximum RGR (Fig. 6A) reached peak values early in the cold season, remained high until the January/February interval, and decreased over the following months. Mean and maximum elongation rates rose more gradually and were highest in the January/ February interval (Fig. 6B). Maximum growth rates remained significantly above zero until April/May (Fig. 6A,B). Reduced growth rates coincided with high proportions of laterals that decreased in size (tissue loss; Fig. 6C). Laterals that decreased in size over the following month were significantly longer than those that increased in size (1-way ANOVAs: $p<0.0001$ in all months). Thus, tissue loss depended on lateral length. Elongation rates also decreased with increasing lateral length in laterals showing positive growth (regression analyses: $p<0.05$ in all months). Elongation rates were unaffected by reproductive status (ANCOVAs on elongation rate by reproductive status, with length as covariate: $p \geq 0.05$ in all months, no interactions). The maximum lateral elongation rate per thallus showed a significant positive correlation with lateral density in several months (regression analyses: November 1999, $F_{1,29}=5.82, \mathrm{p}=0.023 ;$ March 2000, $F_{1,27}=4.52, \mathrm{p}=$

Fig. 5. Sargassum ilicifolium. Size class-frequency distributions of primary laterals at different developmental stages (total number of laterals indicated). Black bars: proportion of laterals without vesicles and receptacles; grey bars: proportion of laterals bearing vesicles but no receptacles; white bars: proportion of laterals bearing receptacles (which usually also bore vesicles). Data based on tagged thalli 
0.043; December 2000, $F_{1,29}=8.127, \mathrm{p}=0.008 ;$ January 2001, $F_{1,29}=7.389, \mathrm{p}=0.011$ ), and regression coefficients were positive also in the other months.

The growth rates shown in Fig. 6 do not include growth that took place prior to the census in which new laterals were first detected, because the time interval over which growth should be calculated is unknown. However, comparison of lateral lengths between newly formed and older laterals showed no significant effect
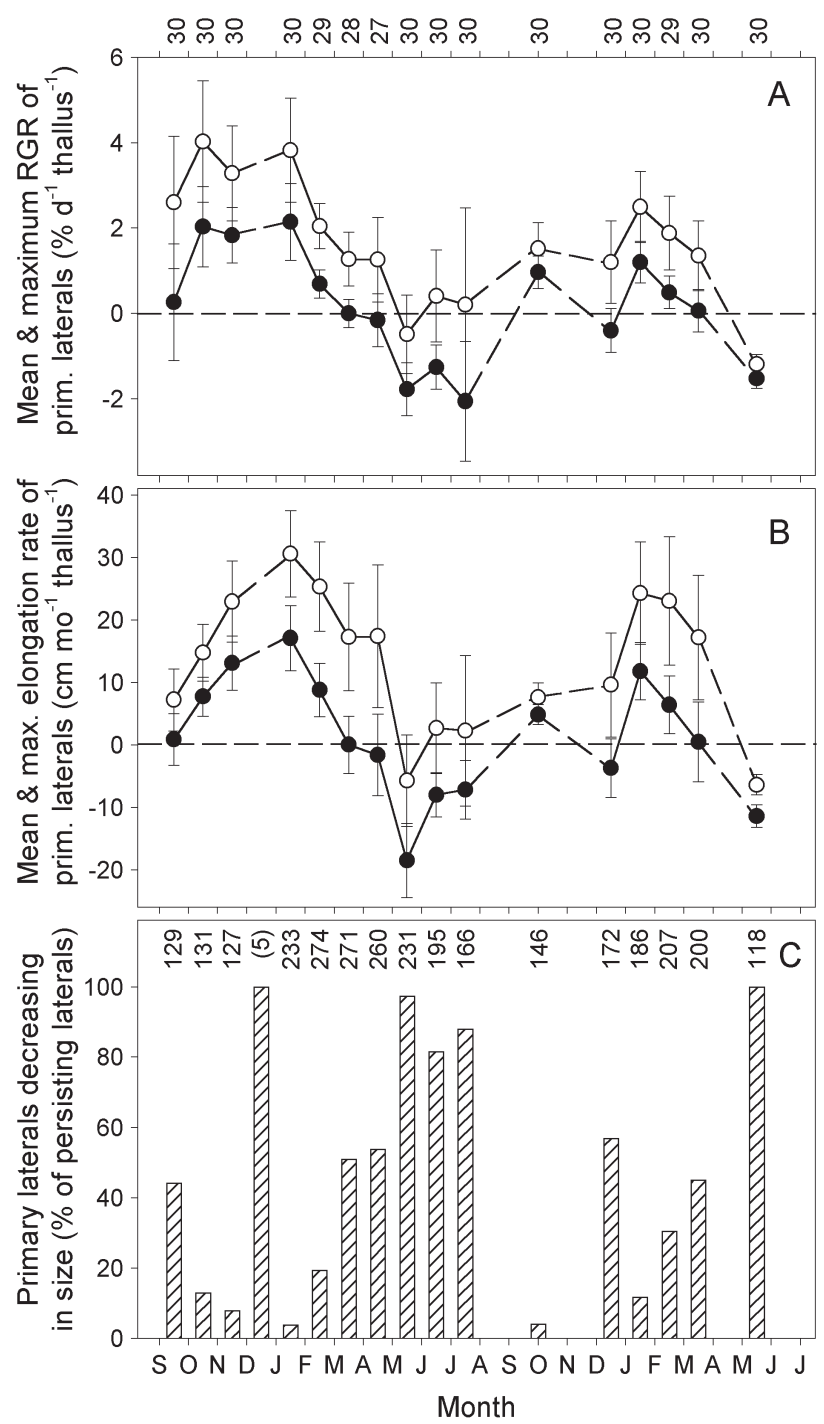

Fig. 6. Sargassum ilicifolium. Growth rate of primary laterals. (A) Mean and maximum relative growth rate per thallus $( \pm$ $\mathrm{SD})$; (B) mean and maximum elongation rate per thallus $( \pm$ $\mathrm{SD})$; (C) proportion of primary laterals decreasing in size (\% of persisting laterals; total number of laterals indicated; value in parenthesis: tag loss). Maximum growth refers to the fastest-growing primary lateral per thallus. Horizontal dotted lines indicate zero growth. For periods when growth was not monitored monthly, mean values are placed in the middle of the intervening period and connected by dashed lines. Data based on tagged laterals; total number of thalli shown on top of age in any month (1-way ANOVAs: $p \geq 0.05$ in SNK post-hoc tests). Thus, newly formed laterals had already reached the same length as the older ones before they were 1 mo old. This implies that laterals go through an early phase of very rapid elongation, especially during months when mean lateral lengths are highest (February to April). During these months, mean elongation rates of the newly formed laterals must have been at least ca $40-45 \mathrm{~cm} \mathrm{mo}^{-1}$ (Fig. 4B), as compared with a maximum elongation rate (thallus ${ }^{-1}$ ) of only ca. 20 to $30 \mathrm{~cm} \mathrm{mo}^{-1}$ in the older laterals (Fig. 6B).

\section{Survivorship of primary laterals}

Survivorship of primary laterals showed distinctive seasonal patterns (Fig. 7). It was highest from August to December and lowest from March to July/August. Of all laterals that were formed in the first cold season, on average about $40 \%$ remained at the onset of the second cold season in December 2000. On average, only about $10 \%$ of these laterals remained at the onset of the second hot season in July 2001. Of the new laterals that were formed in the second cold season, approximately $60 \%$ remained in July 2001. During the period March to June, when loss rates were high (Fig. 7), no significant effect of lateral length on lateral persistence was detected (1-way ANOVAs, $\mathrm{p} \geq 0.05$ in all months). Only in July 2000 were persisting laterals significantly longer than those that were lost (1-way ANOVA: $F_{1,195}=7.419$, $p=0.007)$. The presence of receptacles and/or vesicles had no significant effect on lateral persistence either (chi-square tests: $p \geq 0.05$ in all months between March and July for both stage groups).

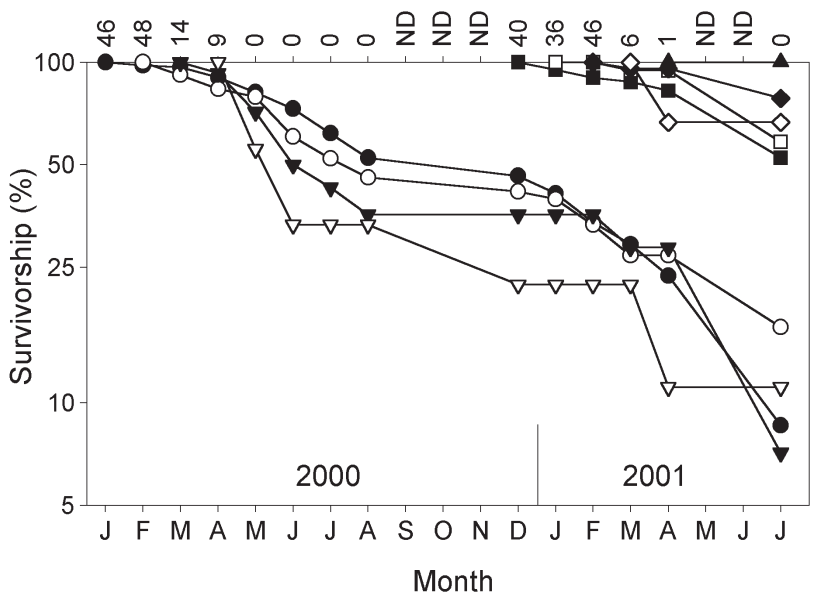

Fig. 7. Sargassum ilicifolium. Survivorship over time of primary laterals formed in different months ( $\log _{10}$-transformed). Number of new laterals in each month indicated above. Data based on tagged laterals 


\section{DISCUSSION}

The phenology of Sargassum ilicifolium shows a predictable seasonal pattern that appears to be closely coupled to seasonal changes in environmental conditions. A summary schedule of the seasonal patterns of growth, thallus length, reproduction, and formation and loss of primary laterals is presented in Fig. 8. The distinct phases in the phenology suggest direct environmental and/or endogenous control of primary lateral initiation, growth, reproduction and shedding. In addition, morphogenetic responses during the development of individual laterals contribute to the overall phenological pattern.

\section{Seasonal patterns in growth rates}

Highest growth rates of Sargassum ilicifolium occur during the cold season at mean temperatures of ca. 28 to $30^{\circ} \mathrm{C}$. In the hot season, when maximum temperatures are ca. 33 to $36^{\circ} \mathrm{C}$, growth rates are below zero. In regions where maximum temperatures are lower, $S$. ilicifolium maintains relatively high biomass all through the year (e.g. The Philippines; mean annual temperature range 29.1 to $32.7^{\circ} \mathrm{C}_{i}$ Hurtado \& Ragaza 1999). At other southern Red Sea localities, where reef flats are typically situated deeper (1.5 to $2 \mathrm{~m}$ ), a high biomass of $S$. ilicifolium was also observed during both the cold and hot seasons (M. Ateweberhan \& J. H. Bruggemann pers. obs.). The higher water-exchange rate seems to prevent excessive heating over these reef flats during the day. De Wreede (1976) and Martin-Smith (1993) suggested that high seawater temperatures are not detrimental to the growth of adult Sargassum thalli. However, maximum temperatures at their study sites (28 and $32^{\circ} \mathrm{C}$, respectively) were considerably lower than on the shallow reefs of the southern Red Sea. Extremely high temperatures led to reduced photosynthesis and increased respiration rates in $S$. polyceratium from Florida (Kilar et al. 1989).

Species-specific differences in growth rates are to be expected among Sargassum species. Mean elongation rates of primary laterals of $S$. ilicifolium (up to ca. $17 \mathrm{~cm}$ $\mathrm{mo}^{-1}$ ) were considerably higher than those reported for S. polyceratium from the Caribbean (up to ca. $7 \mathrm{~cm}$ $\mathrm{mo}^{-1}$; De Ruyter van Steveninck \& Breeman 1987). Mean relative growth rates (up to ca. $2 \% \mathrm{~d}^{-1}$ ) are comparable to those reported for $S$. baccularia from the Great Barrier Reef $\left(G B R\right.$; up to $2.5 \% \mathrm{~d}^{-1}$; Schaffelke \& Klumpp 1997). However, on the GBR highest growth rates occur in summer rather than in winter (annual temperature range 22.6 to $30^{\circ} \mathrm{C}$ ).

Low nutrient levels could enhance adverse effects of high temperatures (Zimmerman \& Kremer 1986, Her-

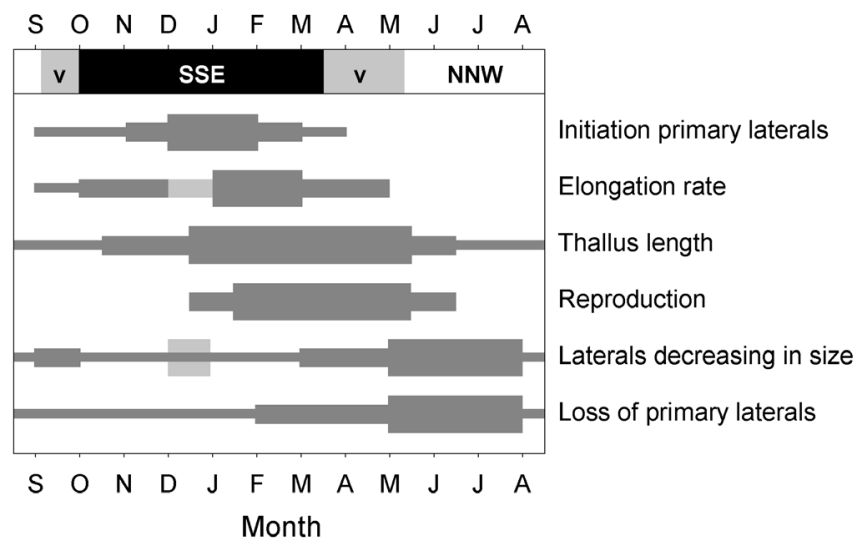

Fig. 8. Sargassum ilicifolium. Diagram of the seasonal dynamics. Bar widths represent different categories relative to the maximum for each parameter: $0 \%$ (no bar) $>>0$ to $25 \%$ (thin bar); 26 to $75 \%$ (intermediate bar); 76 to $100 \%$ (thick bar). Light-shaded bars indicate tissue loss due to siganid grazing (December/January). Data are from Figs. 4A (thallus length), 4D (reproduction), 4E (primary lateral initiation), 6B (maximum elongation rate), 6C (proportion of laterals decreasing in size) and 7 (lateral loss). Bar above indicates the general cycle of monsoon winds in the southern Red Sea: SSE during the cold season (NE monsoon); NNW during the hot season (SW monsoon); $\mathrm{v}=$ transition period with variable wind directions

nandez-Carmona et al. 2001). However, relatively high surface chlorophyll concentrations occur in this region throughout the year (Baars 1994, Van Couwelaar 1997), and southern Red Sea reefs are considered as high nutrient environments (Medio et al. 2000). Therefore, nutrient limitation is probably not the main cause of the observed seasonal variation in Sargassum ilicifolium.

\section{Seasonal dynamics of primary laterals}

The timing of new lateral initiation in Sargassum ilicifolium appears to be a key process in the seasonal cycle. It starts early in the cold season and ends well before the end of the cold season. A restricted period of module formation in highly seasonal environments ensures that modules have sufficient time to grow and reproduce before the onset of the adverse season (Mailette 1992). Such a strategy seems to indicate that S. ilicifolium is a 'season anticipator'. Although 'season anticipators' are well known from temperate regions (Lüning \& tom Dieck 1989) this is the first time a 'season anticipator' strategy has been suggested for a tropical macroalga.

The cessation of new lateral formation occurs during the period of peak reproduction. The metabolic costs of producing receptacles and new laterals at the same time may be too high. Alternatively, new lateral forma- 
tion could be under direct environmental control. Erect thallus formation in Sargassum muticum (Hwang \& Dring 2002) was found to be controlled by photoperiod and to occur in short days only. At our study site $\left(15^{\circ} 35^{\prime} \mathrm{N}\right)$, day length varies between about 11 and $13 \mathrm{~h}$ in the course of the year. A photoperiodic short day response with a sharply defined critical day length of about $12 \mathrm{~h}$, such as found in tropical higher plants (e.g. rice; Thomas \& Vince-Prue 1997), could explain why new laterals in $S$. ilicifolium are formed only from October to April.

The causes of the distinctive seasonal pattern in lateral survivorship are unclear. Loss rates start to increase in spring, during the period when high growth rates indicate favourable conditions. Unexpectedly, loss rates are lowest under the adverse conditions of summer. Conceivably, large lateral sizes could induce higher loss rates. However, we found no significant adverse effect of size on lateral persistence. In many species of Sargassum, reproduction is followed by a period of high lateral loss (e.g. De Wreede 1976, McCourt 1984, Martin-Smith 1993). However, our data do not support the idea that primary lateral loss is a direct consequence of reproduction. Reproductive status had no significant effect on lateral persistence, and some laterals persisted for up to 6 mo while continuing to reproduce. Therefore, the shedding of laterals, like their initiation, may be under direct environmental or endogenous control (Lüning \& tom Dieck 1989).

\section{Effects of lateral density}

Primary lateral density affected the performance of individual laterals in Sargassum ilicifolium. High lateral densities had a positive effect on maximum elongation rates. Faster module elongation at high density has also been found in S. subrepandum, Turbinaria triquetra (Ateweberhan 2004) and other large fucoids (Lazo \& Chapman 1998, Arenas et al. 2002). Low light levels could trigger fast elongation through photomorphogenetic responses, similar to the 'shade avoidance' responses in higher plants (Smith 1982). This would explain the very fast elongation during the earliest phase of a lateral's life span. Newly formed laterals under the cover of the dense canopy of older laterals would experience very low light levels. Their fast elongation to the top of the canopy would allow them to escape from light limitation soon after being formed. Newly formed modules of $S$. subrepandum and T. triquetra also went through an early phase of rapid elongation (Ateweberhan 2004). Thus, studies on growth rates of large canopy algae should consider effects of module age and canopy height as important determinants of growth.
High lateral densities suppressed lateral initiation in Sargassum ilicifolium, as has been reported for other fucoid algae (Lazo \& Chapman 1998, Viejo \& Åberg 2001, Ateweberhan 2004). Module initiation may be density regulated, as a mechanism to avoid overcrowding and competition among modules. However, thallus length had no effect on module initiation in $S$. ilicifolium (this paper), S. subrepandum (Ateweberhan 2004) and Ascophyllum nodosum (Lazo \& Chapman 1998), and light limitation is unlikely to be the proximate determinant of density effects. We suggest that meristem suppression by neighbouring primary laterals may be responsible for the density dependence of lateral initiation.

\section{Seasonal patterns of reproduction}

Reproduction of Sargassum ilicifolium starts in January, when water temperatures are lowest. Season appears to be the main controlling factor. The onset of reproduction is preceded by a period of rapid growth, as has been reported for other Sargassum species (e.g. De Wreede 1976, Prince \& O'Neal 1979, McCourt 1984, Martin-Smith 1993). The overlap in timing between reproduction and maximum canopy development is considered to be advantageous in maximising allocation of resources to reproductive structures (De Wreede \& Klinger 1988). However, this does not imply that reproduction as such is size-dependent. We found no significant difference in length between laterals remaining sterile, becoming fertile or continuing to reproduce. Similar size-independent reproduction was also found in S. subrepandum and Turbinaria triquetra (Ateweberhan 2004). However, fast growth and reproduction are at least partly separated in time within the life span of an individual lateral of $S$. ilicifolium. Primary laterals first go through a phase of rapid elongation before starting to reproduce when 1 to 2 mo old.

\section{Possible trade-off between growth and reproduction}

Traditional views of reproductive allocation postulate a trade-off between growth and reproduction. The existence of such a trade-off has been reported for Sargassum and other fucoid algae (e.g. McCourt 1985, Ang 1992, Åberg 1996, Gillespie \& Critchley 2001). Although we did not measure reproductive allocation as such (see e.g. Gillespie \& Critchley 2001), our data do not support the existence of a direct trade-off between reproduction and growth in S. ilicifolium. We found no significant difference in the growth rate of fertile and sterile laterals. Moreover, many fertile, individually tagged laterals that were followed over many 
months continued to grow. In $S$. polyceratium from the Caribbean, reproduction begins immediately after the initiation of growth (Kilar et al. 1989) and coincides with peak growth (De Ruyter van Steveninck \& Breeman 1987). Thus, a continuation of growth after the onset of reproduction could be common in large canopy algae. We suggest that ontogenetic and morphogenetic responses during the development of an individual lateral may be more important than energetic constraints.

\section{Life history}

Sargassum ilicifolium, like many other Sargassum species, is a 'pseudoperennial'. Plants have the capacity to produce modules repeatedly in consecutive seasons and the advantages of modular construction are expressed not only in a single growth season but are also carried over to subsequent generations of modules. Survival of the holdfast is crucial to longevity and maintenance of the population as it secures suitable substratum already occupied (Fletcher \& Fletcher 1975, De Wreede 1976, Ang 1985, Trono 1992, McCook 1996). Vegetative regeneration appears to predominate over new recruitment in $S$. ilicifolium. Seasonal variation in thallus density was minor, and the average loss rate of established thalli was only ca. $10 \% \mathrm{yr}^{-1}$ (7 tagged thalli over $22 \mathrm{mo}$ ). New recruitment of $S$. ilicifolium might be space-limited, as has been reported for other Sargassum species (Deysher \& Norton 1982, Andrew \& Viejo 1998, Stiger \& Payri 1999).

In the present study we found that all tagged thalli showed a strong increase in length during the cold season. In an earlier study (Ateweberhan 2004), in which the size of all thalli in randomly chosen quadrats was measured, we found many small thalli throughout the cold season. The discrepancy between the 2 studies is probably due to the limited number of tagged thalli $(\mathrm{n}=30$ ) that were monitored. The small thalli could be suppressed in their development in this highdensity population (ca. 175 ind. $\mathrm{m}^{-2}$ ).

\section{The extreme environment of the southern Red Sea}

The extreme seasonal environment in the southern Red Sea permits large macroalgae to dominate on shallow reef flats during the cold season, but their size is strongly reduced during the hot season (Ateweberhan 2004, this paper). The seasonal disintegration of algal tissue obviously releases carbon and nutrients to the adjacent coral-dominated areas. Like temperate kelp beds, where ca $90 \%$ of the macroalgal biomass is recycled through the detrital food chain, coral reefs adjacent to areas with high cover of large Phaeophyta may also be regarded as detritus-driven ecosystems (Marsh 1976, Crossland et al. 1984, Hatcher 1984, Schaffelke \& Klumpp 1997). This indicates the crucial importance of high levels of herbivory for the maintenance of healthy coral reefs in the southern Red Sea.

Adverse effects of high temperatures on large macroalgae, e.g. on Macrocystis populations in the eastern Pacific during El Niño events, are well known (Lüning 1990). The strong die back of canopy algae and the frequent occurrence of coral bleaching in summer (M. Ateweberhan \& J. H. Bruggemann pers. obs.) indicate that species live close to their upper thermal tolerance limits in the southern Red Sea. In fact, summer temperatures at our study site exceed the upper tolerance limits reported for many tropical macroalgae (Pakker et al. 1994). Thus, a rise in seawater temperature due to global warming may be expected to have major consequences for reef communities in these extreme tropical environments.

\section{CONCLUSION}

Thallus density of Sargassum ilicifolium was relatively constant over time, but thallus size showed strong seasonal variation with a predictable pattern. Whole thalli were very persistent, but primary laterals had high turnover. Lateral initiation was restricted to the winter half-year. High lateral densities inhibited the formation of new laterals. Newly formed laterals grew out to the top of the existing canopy before they were 1 mo old. Moreover, high lateral densities promoted faster elongation, suggesting 'shade-avoidance responses'. Survivorship was highest in summer, when laterals survived at a reduced size. Reproduction depended on season rather than on lateral size, but laterals had to be at least 1 to 2 mo old before reproducing. Thus, fast growth and reproduction are partly separated in time within the life span of a lateral. There was no evidence for a direct trade-off between reproduction and growth, nor did reproduction lead to senescence of laterals. Extreme high temperatures on the shallow reef flat in summer, exceeding threshold values for lateral growth, are probably responsible for the observed seasonal variation. In addition, ontogenetic processes during the development of individual laterals determine the dynamic seasonal changes.

Acknowledgements. We thank C. A. Espinosa and W. Prud'homme van Reine at the National Herbarium of The Netherlands, Leiden, for their assistance in the identification of Sargassum. We further thank M. A. J. van Duijn at the Department of Sociology, Statistics \& Measurement Theory of the University of Groningen for advice on statistics. We thank D. Visser for preparing the map. M. A. especially thanks the 
staff and technicians of the Department of Marine Biology, University of Groningen, of the Department of Marine Biology and Fisheries, University of Asmara, and of the Research Unit, Ministry of Fisheries, Eritrea, for their assistance and cooperation during various phases of this work. This study is part of M. A.'s PhD project, which was funded by the Dutch Joint Financing Programme for Cooperation in Higher Education (MHO-NUFFIC). The authors gratefully acknowledge the Dutch Government and the University of Groningen for this funding.

\section{LITERATURE CITED}

Åberg P (1996) Patterns of reproductive effort in the brown alga Ascophyllum nodosum. Mar Ecol Prog Ser 138: 199-207

Andrew NL, Viejo RM (1998) Ecological limits to the invasion of Sargassum muticum in northern Spain. Aquat Bot 60: 251-263

Ang PO Jr (1985) Phenology of Sargassum siliquosum J. Ag. and S. paniculatum J. Ag. (Sargassaceae, Phaeophyta) in the reef flat of Balibago, Calatagan, Philippines. Proc 5th Int Coral Reef Congr 5:51-57

Ang PO Jr (1986) Analysis of the vegetation structure of a Sargassum community in the Philippines. Mar Ecol Prog Ser 28:9-19

Ang PO Jr (1992) Cost of reproduction in Fucus distichus. Mar Ecol Prog Ser 89:25-35

Arenas F, Viejo RM, Fernández C (2002) Density-dependent regulation in an invasive seaweed: responses at plant and modular levels. J Ecol 90:820-829

Ateweberhan M (2004) Seasonal dynamics of coral reef algae in the southern Red Sea: functional group and population ecology. PhD thesis, University of Groningen

Baars MA (ed) (1994) Monsoons and pelagic systems. Cruise Reports, Netherlands Indian Ocean Programme, Vol I. National Museum of Natural History, Leiden

Begon M, Townsend CR, Harper JL (1990) Ecology: individuals, populations and communities. Blackwell, Boston

Crossland CJ, Hatcher BG, Atkinson MJ, Smith SV (1984) Dissolved nutrients of a high latitude coral reef, Houtman Abrolhos Islands, Western Australia. Mar Ecol Prog Ser 14:159-163

De Guimaraens MA, Coutinho R (1996) Spatial and temporal variation of benthic marine algae at the Cabo Frio upwelling region, Rio de Janeiro, Brazil. Aquat Bot 52: 283-299

De Ruyter van Steveninck ED, Breeman AM (1987) Population dynamics of a tropical intertidal and deep water population of Sargassum polyceratium (Phaeophyceae). Aquat Bot 29:139-156

De Wreede RE (1976) The phenology of three species of Sargassum (Sargassaceae, Phaeophyta) in Hawaii. Phycologia 15:175-183

De Wreede RE, Klinger T (1988) Reproductive strategies in algae. In: Lovett DJ, Lovett DL (eds) Plant reproductive ecology: patterns and strategies. Oxford University Press, New York, p 267-284

Deysher L, Norton TA (1982) Dispersal and colonization in Sargassum muticum (Yendo) Fensholt. J Exp Mar Biol Ecol 56:179-195

Fantoli A (1966) Contributo alla climatologica dell' altopiano Etiopico, Regione Eritrea. Ministero degli affari esteri, Cooperazione scientifica e tecnica. Bibliotheca del Istituto Italiano per l'Africa, Rome

Fletcher RL, Fletcher SM (1975) Studies on the recently intro- duced brown alga Sargassum muticum (Yendo) Fensholt I. Ecology and reproduction. Bot Mar 18:149-156

Gillespie RD, Critchley AT (2001) Reproductive allocation and strategy of Sargassum elegans Suhr and Sargassum incisifolium (Turner) C. Agardh from Reunion Rocks, KwaZuluNatal, South Africa. Bot Mar 44:231-235

Glenn EP, Smith CM Doty MS (1990) Influence of antecedent water temperatures on standing crop of a Sargassum spp.dominated reef flat in Hawaii. Mar Biol 105:323-328

Guillaume MM, Bruggemann JH, Futwi M, Heruy A (2000) Corals on the edge in the Red hot Sea: temperatures and annual bleaching on near-shore reefs in Eritrea. In: Proc 9th Int Coral Reef Symp, Bali, Indonesia. Abstracts, p 263

Hales JM, Fletcher RL (1990). Studies on the recently introduced brown alga Sargassum muticum (Yendo) Fensholt. $\mathrm{V}$. Receptacle initiation and growth, and gamete release in laboratory culture. Bot Mar 33:241-249

Hatcher BG (1984) A marine accident provides evidence for alternate stable states in benthic communities on coral reefs. Coral Reefs 3:199-204

Hernandez-Carmona G, Robledo D, Serviere ZE (2001) Effect of nutrient availability on Macrocystis pyrifera recruitment and survival near its southern limit off Baja California. Bot Mar 44:221-229

Hurtado AQ, Ragaza AR (1999) Sargassum studies in Currimao, Ilocos Norte, Northern Philippines. I. Seasonal variations in the biomass of Sargassum carpophyllum, S. ilicifolium and $S$. siliquosum (Phaeophyta, Sargassaceae). Bot Mar 42:321-325

Hwang EK, Dring MJ (2002) Quantitative photoperiodic control of erect thallus production in Sargassum muticum. Bot Mar 45:471-475

Kendrick GA, Walker DI (1991) Dispersal distances for propagules of Sargassum spinuligerum (Sargassaceae, Phaeophyta) measured directly by vital staining and venturi suction sampling. Mar Ecol Prog Ser 79:133-138

Kendrick GA, Walker DI (1995) Dispersal of propagules of Sargassum spp. (Sargassaceae, Phaeophyta): observations of local patterns of dispersal and consequences for recruitment and population structure. J Exp Mar Biol Ecol 192: 273-288

Kilar JA, Littler MM, Littler DS (1989) Functional-morphological relationships in Sargassum polyceratium (Phaeophyta): phenotypic and ontogenetic variability in apparent photosynthesis and dark respiration. J Phycol 25:713-720

Lazo ML, Chapman ARO (1998) Components of crowding in a modular seaweed: sorting through the contradictions. Mar Ecol Prog Ser 174:257-267

Lipkin Y (1987) Marine vegetation of the Museri and Entedebir Islands (Dahlak Archipelago, Red Sea. Isr J Bot 36: 87-99

Lüning K (1990) Seaweeds: their environment, biogeography and ecophysiology. John Wiley \& Sons, New York

Lüning K, tom Dieck I (1989) Environmental triggers in algal seasonality. Bot Mar 32:389-397

Mailette L (1992) Seasonal model of modular growth in plants. J Ecol 80:123-130

Marsh JA (1976) Energetic role of algae in reef ecosystems. Micronesica 12:13-21

Martin-Smith KM (1993) The phenology of four species of Sargassum at Magnetic Island, Australia. Bot Mar 36: 327-334

McCook LJ (1996) Effects of herbivores and water quality on the distribution of Sargassum on the Central Great Barrier Reef: cross shelf transplants. Mar Ecol Prog Ser 139: 179-192

McCook LJ (1997) Effects of herbivory on zonation of Sargas- 
sum spp. within fringing reefs of the central Great Barrier Reef. Mar Biol 129:713-722

McCook LJ (1999) Macroalgae, nutrients and phase shifts on coral reefs: scientific issues and management consequences for the Great Barrier Reef. Coral Reefs 18:357-367

McCourt RM (1984) Seasonal patterns of abundance, distributions and phenology in relation to growth strategies of three Sargassum species. J Exp Mar Biol Ecol 74:141-156

McCourt RM (1985) Reproductive biomass allocation in three Sargassum species. Oecologia 67:113-117

McLachlan J, Bidwell RGS (1978) Photosynthesis of eggs, sperms, zygotes and embryos of Fucus serratus. Can J Bot 56:371-373

Medio D, Sheppard CRC, Gascoigne J (2000) The Red Sea. In: McClanahan TR, Sheppard, CRC, Obura DO (eds) Coral reefs of the Indian Ocean - their ecology and conservation. Oxford University Press, New York, p 231-235

Mergner H, Svoboda A (1977) Productivity and seasonal changes in selected reef areas in the Gulf of Aqaba (Red Sea). Helgol Wiss Meeresunters 30:383-399

Morcos SA (1970) Physical and chemical oceanography of the Red Sea. Mar Biol Annu Rev 8:73-202

Pakker H, Breeman AM, Prud'homme van Reine WF, Van den Hoek C (1995) A comparative study of temperature responses of Caribbean seaweeds from different biogeographic groups. J Phycol 31:499-507

Prince JS (1980) The ecology of Sargassum pteropleuron Grunow (Phaeophyceae, Fucales) in the waters off South Florida. II. Seasonal photosynthesis and respiration of $S$. pteropleuron and comparison of its phenology with that of S. polyceratium Montagne. Phycologia 19:190-193

Prince JS, O'Neal SW (1979) The ecology of Sargassum pteropleuron Grunow (Phaeophyceae, Fucales) in the waters off South Florida. I. Growth, reproduction and population structure. Phycologia 18:109-114

Rogers RW (1997) Brown algae on Heron Reef Flat, Great Barrier Reef, Australia: spatial, seasonal and secular variation in cover. Bot Mar 40:113-117

Schaffelke B, Klumpp DW (1997) Biomass and productivity of tropical macroalgae on three nearshore fringing reefs in the central Great Barrier Reef, Australia. Bot Mar 40:373-383

Sheppard CRC (2000) Coral reefs of the western Indian Ocean: an overview. In: McClanahan TR, Sheppard CRC, Obura DO (eds) Coral reefs of the Indian Ocean-their ecology and conservation. Oxford University Press, New York, p 3-38

Sheppard CRC, Price A, Roberts C (1992) Marine ecology of the Arabian Region: patterns and processes in extreme tropical environments. Academic Press, London

Silva PC, Basson PW, Moe RL (1996) Catalogue of the benthic marine algae of the Indian Ocean. University of California, Berkeley, CA

Editorial responsibility: Otto Kinne (Editor-in-Chief), Oldendorf/Luhe, Germany
Smith H (1982) Light quality, photoperception and plant strategy. Annu Rev Plant Physiol 33:481-518

Sokal RR, Rohlf FJ (1995) Biometry, 3rd edn. WH Freeman, New York

Srinivasan KS (1967) Conspectus of Sargassum species from Indian territorial waters. Phykos 5:127-159

Stevens J (2002) Applied multivariate statistics for the social sciences, 4th edn. Lawrence Erlbaum Assoc, Mahwah, NJ

Stiger V, Payri CE (1999) Spatial and temporal patterns of settlement of the brown macroalga Turbinaria ornata and Sargassum mangarevense in a coral reef on Tahiti. Mar Ecol Prog Ser 191:91-100

Thomas B, Vince-Prue D (1997) Photoperiodism in plants, 2nd edn. Academic Press, San Diego, CA

Trono GC Jr (1992) The genus Sargassum in the Philippines. In: Abbott IA (ed) Taxonomy of economic seaweeds with reference to some Pacific and Western Atlantic species. University of California, La Jolla, CA, p 43-94

Trono GC Jr, Tolentino GL (1993) The reproductive phenology of Sargassum spp. (Fucales, Phaeophyta) in Bolinao, Pangasinan. Proc 2nd RP-USA Phycol Symp 2:181-193

Tsuda RT (1972) Morphological, zonational and seasonal studies of 2 species of Sargassum on the reefs of Guam. In: Proc 7th Int Seaweed Symp, Sapporo, Japan. University of Tokyo Press, Tokyo, p 40-44

Underwood AJ (1997) Experiments in ecology: their logical design and interpretation using analysis of variance. Cambridge University Press, Cambridge

Van Couwelaar M (1997). Zooplankton and micronekton biomass off Somalia and in the southern Red Sea during the SW monsoon of 1992 and the NE monsoon of 1993. DeepSea Res 44:1213-1234

Viejo RM, Åberg P (2001) Effects of density on the vital rates of a modular seaweed. Mar Ecol Prog Ser 221:105-115

Vuki VC, Price IR (1994) Seasonal changes in the Sargassum populations on a fringing coral reef, Magnetic Island, Great Barrier Reef region, Australia. Aquat Bot 48: 153-166

Walker DI (1987) Benthic algae. In: Edwards FJ, Head MS (eds) Key environments: Red Sea. Pergamon, Oxford, p 152-168

Wanders JB (1976) The role of benthic algae in the shallow reef of Curaçao (Netherlands Antilles). II. Primary productivity of the Sargassum beds on the north east coast submarine plateau. Aquat Bot 2:327-335

Zar J (1996) Biostatistical analysis, 3rd edn. Prentice Hall, London

Zimmerman RC, Kremer JN (1986) In situ growth and chemical composition of the giant kelp, Macrocystis pyrifera: response to temporal changes in ambient nutrient availability. Mar Ecol Prog Ser 27:277-285

Submitted: May 5, 2004; Accepted: December 23, 2004

Proofs received from author(s): April 18, 2005 